NBER WORKING PAPER SERIES

\author{
PRESENT AT THE REVOLUTION: \\ TRANSFORMATION OF TECHNICAL \\ IDENTITY FOR A LARGE INCUMBENT \\ PHARMACEUTICAL FIRM AFTER THE \\ BIOTECHNOLOGICAL BREAKTHROUGH
}

Lynne G. Zucker

Michael R. Darby

Working Paper 5243

\author{
NATIONAL BUREAU OF ECONOMIC RESEARCH \\ 1050 Massachusetts Avenue \\ Cambridge, MA 02138 \\ August 1995
}

This research has been supported by grants from the Alfred P. Sloan Foundation through the NBER Research Program on Industrial Technology and Productivity, the National Science Foundation (SES 9012925), the University of California Systemwide Biotechnology Research and Education Program, the University of California Systemwide Pacific Rim Research Program, the UCLA Center for American Politics and Public Policy, and the UCLA Institute of Industrial Relations. It would not have been possible without the assistance of Martin Feldstein in gaining access to the firm studied. Useful comments on earlier drafts have been received from Douglas L. Cocks, William Comanor, Timothy L. Hunt, Michael Intriligator, Jeffrey L. Tarlowe, and other participants in presentations to the Industry Ad-Hoc Working Group on the Economics of the Pharmaceutical Industry and the joint Pharmaceuticals Workshop of the UCLA Departments of Health Services and Economics. Principal research assistance for this paper was provided by Maximo Torero and Jeff Armstrong. We are indebted to a remarkably talented team of postdoctoral fellows Zhong Deng, Julia Liebeskind, and Yusheng Peng and research assistants Paul J. Alapat, Jeff Armstrong, Cherie Barba, Lynda J. Kim, Kerry Knight, Edmundo Murrugara, Amalya Oliver, Alan Paul, Erika Rick, Maximo Torero, Alan Wang, and Mavis Wu. This paper is part of NBER's research program in Productivity. Any opinions expressed are those of the authors and not those of the National Bureau of Economic Research.

(C) 1995 by Lynne G. Zucker and Michael R. Darby. All rights reserved. Short sections of text, not to exceed two paragraphs, may be quoted without explicit permission provided that full credit, including (c) notice, is given to the source. 


\title{
PRESENT AT THE REVOLUTION: TRANSFORMATION OF TECHNICAL IDENTITY FOR A LARGE INCUMBENT PHARMACEUTICAL FIRM AFTER THE BIOTECHNOLOGICAL BREAKTHROUGH
}

\begin{abstract}
This paper is a case study of the transformation in research methods which occurred in a large U.S. pharmaceutical firm as a result of the biotechnology revolution. This transformation is inconsistent with the hypothesis that technological revolutions make existing firms obsolete (because of rigidity of core task routines) and consistent with our wealth-maximization hypothesis under which valuable assets (such as delivery know-how and other complementary technologies) will not be wasted if technological change in part of the organization is necessary for the remainder to maintain its competitiveness. While the transformation was achieved through a variety of methods, the primary route was hiring new personnel possessing the new technology and incorporating them into the existing structure.

While the technological transformation has been profound, biotechnology applications in this large incumbent firm are more likely to be used in combination with other technologies than in the new biotechnology firms (NBFs) which tend to use biotechnology for both discovery and production of new therapeutic entities. This difference in emphasis may result in value-enhancing synergies because of the wealth of related knowledge which makes for more effective applications of the new technologies, but it could also retard full adoption of biotechnology. Resolution of this empirical question is the subject of future research.

It appears that this firm was somewhat slower than the dedicated biotech firms to adopt the new technology, but once the decision was made to transform the technological identity of the firm massive resources were provided to recruit the intellectual human capital required to make it happen. We conducted a preliminary analysis of data for this and other major pharmaceutical firms on the extent of publication by top "star" scientists either affiliated with the firm or writing with scientists from the firm -- a powerful predictor of successful application of biotechnology. Patenting of genetic sequences by these firms as well as corresponding NBFs was also examined. The incumbent firms were generally slow to adopt biotechnology, but as a group made great strides in the late 1980s in increasing their share of all commercial ties to the star scientists as well as their share of patents.
\end{abstract}

Lynne G. Zucker

Department of Sociology

University of California, Los Angeles

Los Angeles, CA 90095-1551

and NBER
Michael R. Darby

Anderson Graduate School of Management

University of California, Los Angeles

Los Angeles, CA 90095-1481

and NBER 


\title{
PRESENT AT THE REVOLUTION: \\ TRANSFORMATION OF TECHNICAL IDENTITY FOR A LARGE INCUMBENT \\ PHARMACEUTICAL FIRM AFTER THE BIOTECHNOLOGICAL BREAKTHROUGH
}

\author{
by Lynne G. Zucker and Michael R. Darby
}

This paper is a case study of the transformation in research methods resulting from the biotechnology revolution which occurred in a large U.S. pharmaceutical firm. More fundamentally, this paper is a contribution to a literature dealing with the sources of persistent differences in the performances of firms in an industry. We examine the issue of whether the collection of embodied information and task routines which make up the technological identity of a firm necessarily carry the seeds of the firm's destruction when a technological breakthrough converts that identity from a competitive advantage to disadvantage. We present some strong counter-evidence to the assumption of an immutable technological identity as well as grounding some observable measures of change for use in cross-sectional statistical work.

In Economics 101, the standard model assumes that each firm has access to all the technological information relevant to the industry and acquires resources in competitive markets so the production and cost functions of each firm are the same and entry and exit proceeds until there are $\mathrm{n}$ identical firms, each producing the same output and earning zero economic profits. While the simple model is adequate for analysis of many important problems, it clearly does great violence to the actual variety of firm sizes, productivities, and profitabilities observed in real industries.

It is possible to consider industry equilibriums in which output and productivity of firms vary by assuming variations in "entrepreneurial capacity" which lead to individual firms to possess idiosyncratic production functions; any apparent variations in accounting profitability would reflect, in this paradigm, a failure to capitalize the quasi-rents due to the proprietor's 
entrepreneurial capacity and thus do not represent real economic profits but only a problem in accounting. ${ }^{1}$

Since the entrepreneurial-capacity approach at best labels our ignorance and at worst does considerable violence to the sources of persistence differences in corporate performance in modern industry, scholars of economics, management, and organization have attempted to identify specific (preferably quantifiable) factors which are the source of such persistent performance differences. Aside from the theoretically uninteresting but empirically important accounting issues, the currently dominant explanation for persistent differences is found in the work of Nelson and Winter (1982) and their followers.

Nelson and Winter (1982) see organizations as separable from the sum of their parts because they embody particular information about how to do things in a set of task routines which require little direct intervention by management to ensure that the work of the organization gets done. For organizations in technologically based industries, these task routines and the embodied knowledge they represent will determine the technological identity of the firm. Thus, a firm can have a kind of organizational capital which provides a continuing competitive advantage. Competitors cannot eliminate this competitive advantage by hiring away individual employees, although we occasionally see suits over firms hiring a large number of employees in an attempt to replicate these task routines.

Because the technological identity of a great high-technology firm has been the source of its strength, it may be difficult to change what has worked so well and -- for a time -- will continue to produce supranormal earnings in the face of a breakthrough change in technology which will ultimately convert that strength to an outmoded, uncompetitive technology. At one extreme, the population-ecology approach to describing the evolution of the number and composition of firms is based on the maintained assumption that the technological identity, the 
"technological core," of the firm is immutable (Michael T. Hannan and John Freeman 1984). ${ }^{2}$ A broader literature argues that while the technological identity of the firm is not literally immutable, changes may be difficult to achieve and technological breakthroughs -- particularly those of uncertain value -- will often result in the birth of new firms whose technological identities encompass the new technology and these firms replace the formerly dominant prebreakthrough incumbents (see, for example, Jennifer F. Reinganum 1983 and 1989, Bo Hedberg 1981, Michael L. Tushman and Philip Anderson 1986, Rebecca Henderson and Kim B. Clark 1990, and Henderson 1993). Elise Brezis, Paul Krugman, and Daniel Tsiddon (1991) use a technological-identity type argument to argue that radical breakthroughs in technology can lead to a poorer country overtaking and passing a richer country.

The paper is organized as follows: Section I provides a primer on the biotech revolution and some of the concepts we have been using to examine the development of bioscience and its commercialization. Section II presents the goals and hypotheses of the case study. We then turn to reporting what we learned about how this major firm transformed its technological identity to the point that its scientists can claim that there is no difference between it and a large new biotech firm in how research is done. We next report the firm's approach to collaborations with scientists at universities and at other firms in Section IV. In Section V, we present some evidence on how generalizable the case study may be by comparing this and other major pharmaceutical firms with the dedicated biotech firms in terms of their access to leading-edge scientists and their genetic-sequence patenting success. Our conclusions are in Section VI. 


\section{Issues for the Case Study: The Biotech Revolution and the Pharmaceutical Industry}

The biotechnological revolution is an outstanding example of the type of technological breakthrough which evolutionary theorists hypothesize will lead to the replacement of previously dominant incumbent firms by newly created firms which encompass the new technology in their technical identity. With our associates, we have been studying the development and diffusion of bioscience and its application in a variety of industries including the pharmaceutical, medical supply, chemical, agricultural, food-processing, and brewing. In this paper, however, we concentrate particularly on applications to the pharmaceutical industry defined as creators, manufacturers, and marketers of human therapeutics, vaccines, and diagnostics. ${ }^{3}$

\section{What Is the Biotech Revolution?}

Broadly enough defined, biotechnology has been used as long as people have baked bread and drank wine. Cross breeding of animals and growing penicillin are other examples of such traditional forms of biotechnology. Today, biotechnology or biotech is generally defined more narrowly in terms of using breakthrough technologies such as genetic engineering. An excellent working definition of biotechnology, as noted by a respondent at the subject firm of the case study, would be as follows:

In discussing biotechnology at [the firm], I use biotechnology to mean the revolutionary breakthroughs in life sciences over the last two decades including especially the use of recombinant DNA (rDNA) to create living organisms and their cellular, subcellular, and molecular components as a basis for producing both therapeutics and targets for testing and developing therapeutics. Recent developments focus on structural biology, combinatorial chemistry, and gene 
therapy.

In our research we date the beginning of the biotech revolution in bioscience with the 1973 discovery by Stanford professor Stanley Cohen and University of California-San Francisco professor Herbert Boyer of the basic technique for recombinant DNA (rDNA) ${ }^{4}$ The commercial applications of biotechnology followed quickly in new biotechnology enterprises formed as early as 1976 . Robert D. Sindelar $(1992,1993)$ provides a useful introduction to these applications in the pharmaceutical industry. ${ }^{5}$

The revolution in bioscience is not completed nor is it entirely clear what will ultimately prove its most important areas of applications in the pharmaceutical industry. It is clear, however, that biotech is a dominant technology for at least some areas of production of biological agents, for creation of targets for screening and evaluating potential pharmaceutical products, and as a methodological base for creating potential pharmaceutical products. Currently, firms in the industry are undergoing a shakeout both as it becomes easier to separate the most effective from the less effective of those firms using the new technologies and also as government and regulatory initiatives impact anticipated future and current profitablity in the pharmaceutical industry. Nonetheless, it is clear that biotech is a dominant technology even as it is unclear what will be the makeup of the industry in which it will be utilized.

\section{Measurements of Intellectual Human Capital}

One way to understand what has driven the evolution of industrial biotech applications to date and may determine the ultimately most successful firms in the pharmaceutical industry is to examine the scientific base or intellectual human capital which is the key resource for this industry. The pharmaceutical industry combines a heavy research component aimed at creating and identifying new chemical and biological entities which may safely and effectively alleviate 
or cure diseases, a testing component which establishes which of those entities are in fact safe and effective in patients, a regulatory component which assembles the testing data and manages the submissions of marketing approval applications to drug regulatory agencies worldwide, a manufacturing component which actually manufactures the drugs when they have been approved, and a marketing component which informs doctors (and in some cases patients) of the availability and utility of approved drugs. The costs involved in bringing a new drug to market are tremendous with a recent U.S. Office of Technology Assessment report (1993, p. 67) placing the total costs at up to $\$ 359$ million (1990 dollars) for new drugs approved in the 1970 s including the prorata cost of failed drug candidates and accrued interest on the outlays accumulated to date of marketing approval. ${ }^{6}$ Only about three out of ten of the drugs approved ever earn net revenues (over their manufacturing and marketing costs) sufficient to cover their share of the research, testing, and regulatory costs of creating new therapies (Grabowski and Vernon 1994). The best firms are those that more efficiently develop and select for testing drugs likely to be major revenue producers and that manage to go through the process relatively quickly -- eight to twelve years is a normal range -- so that accrued interest costs on past investment are reduced (DiMasi, Grabowski, and Vernon 1994).

Given the nature of the industry as just outlined, it is easy to see that, other things equal, firms with the best scientists are likely to be the most successful. ${ }^{7}$ In our larger project on bioscience and its applications, we have used and validated one particular way of identifying the best scientists in this field. A very important measure of research success is the discovery of nucleotide sequences that determine the characteristics of proteins and other molecules. Scientists in the field use a data base GenBank to report and access information on such discoveries. Based on GenBank reports, we identified 327 leading researchers whom we termed "stars" on the basis of the number of unique genetic sequences reported up to 1990 in articles for which they were 
an author and on the number of such articles. ${ }^{8}$ These 327 stars were listed as authors on 4,061 distinct articles in major journals. ${ }^{9}$ These articles were hand collected to identify and locate institutional affiliations at the time of publication for each of our stars and their coauthors. Because research discoveries frequently occurred through teams, another 6,082 scientists who were coauthors with a star but who had not themselves met the star criteria were labeled "collaborators." We also found it useful for some purposes to look only at "active" stars or collaborators who have been listed as an author of three of more of our set of articles in the current or two prior years.

Intellectual capital so defined is rather concentrated in location. In the United States, only 242 distinct organizations were given at any time as affiliations of any of the stars or collaborators in our articles data set. These organizations comprised 120 universities, 74 research institutes and hospitals, and 48 firms. Of course, scientists may have secondary affiliations such as service on scientific advisory boards with a number of other organizations which they do not list and so which would not be reflected in our data set.

\section{Intellectual Human Capital and the Evolution of Industrial Biotechnology}

Zucker, Darby, and Brewer (1994) demonstrates that where and when U.S. new biotechnology enterprises (NBEs) are formed is determined primarily by intellectual human capital variables: by where and when star scientists were actively publishing, by the location of universities with top-ranked bioscience departments, and by the number of university scientists funded by the federal government. Firms were linked to the science base geographically using functional economic areas (which we called BEAs in honor of their defining organization, the U.S. Bureau of Economic Analysis) as the basic unit of analysis. We found that the number of stars' collaborators in the area -- even when limited to those actively publishing -- had no 
measurable effect until the late 1980s as the science became more routinized.

As reported in Table 1, our findings for NBEs in all industries are very similar to those obtained with separate analyses of the data broken down by whether the NBE is a new biotech firm (NBF) founded after 1975 or is a new subunit or subsidiary (NBS) of a pre-existing firm such as a large pharmaceutical company. ${ }^{10}$ Stars are important determinants of where and when NBFs, NBSs, and NBEs are founded in the first decade of industrial application, but their role appears to be taken over by their collaborators after 1985 . The most important observation for current purposes is that pre-existing firms seemed to enter biotech in response to much the same forces as caused entry of new firms. This would seem to contradict the popular view that firms have at least relatively immutable technological identities.

Since birth of organizations does not show whether they will be successful, Zucker, Darby, and Armstrong (1994) builds on this earlier research to examine the effects of universitybased star scientists on three measures of performance for California biotechnology enterprises (both NBFs and NBSs combined): the number of products in development, the number of products on the market, and changes in employment. The number of these stars has a significantly positive effect at least for products in development, apparently indicating geographically localized knowledge spillovers. However, when we break down university stars into those who have collaborated on publications with scientists affiliated with the firm and all other university stars, there is a very strong positive effect of the linked stars on all three firmperformance measures and little or no evidence of an effect from the other university stars. We develop a new hypothesis of geographically localized effects of university research which is consistent with market exchange -- namely that apparent spillovers are in fact the productivity effects of (usually) unmeasured market transactions between professors and enterprises.

For two of the three dependent variables (number of products in development and the 
number of products on the market), there were significant differences between NBFs and NBSs as illustrated in Tables 2 and $3 .{ }^{11}$ Other things equal, NBFs have about one and a third more products in development than NBSs, but NBSs have about one third more product actually on the market. Since products in development generally seem to be more substantial than those already on the market in 1990 (often reagents or instruments), at first glance four in the bush would seem to be better than one in hand. However, an alternative view is that NBSs are better at focussing on projects more likely to payoff and thus there is a better output/input ratio. Moreover, other things equal, employment growth from 1989 to 1994 was somewhat higher for NBSs than NBFs although the differences were not statistically significant. 


\section{Case Study -- Introduction}

Theory provides no reliable guide to how a successful incumbent firm will respond to a major technological breakthrough although most scholars specifically considering the issue seem to argue that it is difficult, if not impossible, for a firm to change radically its technological identity. Our empirical work exploiting a rich relational data base on bioscience and its commercial applications seems to deliver conflicting messages: incumbent firms enter biotechnology in response to similar factors as give birth to new dedicated biotech firms, but the typical NBS have significantly fewer products in development and significantly more products on the market than does the typical NBF.

Our earlier empirical work was grounded by case studies of NBFs in the U.S. and the U.K. and fieldwork on four NBSs in Japan, and we believed that the next step was to conduct a case study on the introduction and diffusion of biotechnological methods in a successful major pharmaceutical firm based in the United States. Fortunately, we were able to obtain the cooperation of one such firm.

This firm is widely and correctly regarded as one of the most successful pharmaceutical companies in the world, with an enviable record of science-based drug discovery and development, outstanding abilities in the management of clinical testing, excellent ability to shepherd a New Drug Application (NDA) through the F.D.A.in as short a time as possible, and a first rate marketing group to effectively distribute the products when they are approved. It is one of a handful of such firms in the U.S., each endowed with a workforce both proud of their company -- which they believe the best among some outstanding competitors -- and very pleased that their personal success is in direct proportion to their ability to contribute to reducing suffering and death among victims of disease. We were personally grateful for the opportunity 
to get to know the people we worked with.

Talking with people with such justified pride in themselves and their company, we found it easy to see why economists and management strategists would hypothesize that it would prove difficult, if not impossible, to tamper with a proven formula for success. Nonetheless, we found that the ethos of this science-driven company valued innovation and that there was great pride taken in the firm's ability to continuously change how it did its research and development, so that ongoing technological change appeared to be an integral part of the firm's identity. ${ }^{12}$

\section{Goals and Hypotheses}

At the outset, we wanted to shed light on two basic hypotheses about the ability of successful incumbent firms to transform their technological identities:

Ho Immutability: Firms are born with a technological identity and flourish when that identity has a competitive advantage. In the face of a radical technological breakthrough which makes another technology requiring different human capital dominant, previously successful incumbent firms will be unable to change and will ultimately be replaced by new firms with the newly dominant technological identity.

H1 Persistent Success: In the face of a radical technological breakthrough which makes another technology requiring different human capital dominant, (at least some) successful incumbent firms will change the relevant part of their technological identity -- bringing in new human capital -- so that the value of their other assets is not wasted.

We knew from our relational data base and empirical results, as well as the work of others, that the case-study firm would in fact be an example of technological transformation supporting $\mathrm{H} 1$ relative to $\mathrm{H} 0$. So our practical goals were not to provide a counterexample of $\mathrm{H} 0$-- which could be done with much less work -- but to understand the organizational mechanisms of 
transformation and whether the firm's possession of complementary organizational assets in R\&D, as well as in the testing, regulatory, and marketing areas, led to differences in how the firm commercialized the breakthroughs in bioscience as compared to the dedicated NBFs born lacking such assets. Since our earlier work had demonstrated that access to and working with truly top university bioscientists seems to be powerfully linked to success, we were particularly interested in seeing how this firm regarded and used such linkages. 


\section{The Process of Technological Transformation}

The firm views itself currently as technologically indistinguishable in research and development from any of the best large dedicated biotech firms. The transformation from some involvement to state of the art is seen as occurring between 1985 and $1990 .{ }^{13}$ While a few NBFs were founded between 1976 and 1979 , most were founded in the 1980 s so this transformation might be characterized as lagging the commercial application of the new technology by no more than about five years. In terms of employment, this firm is one of the very largest biotech enterprises based on its self-characterization.

\section{The Drivers of the Transformation}

Firm respondents clearly see the process of transformation as driven by top managers who were technically competent to evaluate the importance of the bioscience breakthroughs to the pharmaceutical industry and had the vision to devote the resources necessary to ensure that the firm became a world leader in the use of those breakthroughs. ${ }^{14}$ These managers included the firm's CEO and the head of the R\&D group during the period of transformation. The individual who was the CEO had earlier played a leading role in initiating one of the first biotech collaborations at the firm. ${ }^{15}$

\section{The Process of Transformation}

In the early 1980s, some research groups at the firm were utilizing biotechnology, but it was not a general practice nor one consciously fostered. In 1985, with the appointment as head of the research group of a molecular biologist who had the full support of the CEO, the conscious effort to transform how the firm did drug discovery began. Biotechnology was introduced 
through focussed groups -- or SWAT teams -- at this time. Over a period of three or four years, the firm's scientists generally switched to cloned human targets (receptors, proteins, enzymes, DNA) for initial testing of prospective drugs. ${ }^{16}$ The firm's Japanese labs were operated independently and only recently have begun the same transformation under new leadership. By 1990 , biotech had permeated the entire research organization, become "central to the way we do drug discovery," and the remaining SWAT teams were eliminated as most of their members had already transferred to research teams focussed on particular types of disease. In 1994, the firm hired another of our star scientists to lead developments in the area of gene therapy.

The firm's own biotechnology revolution was accomplished primarily by hiring people knowledgeable in the technology during a period of rapid growth throughout the 1980s and early 1990s:

The strategy was to hire lots of excellent people to grow our strength in bioscience in the late 1980s. [We] can hire from the best teams because the new biotechnology firms legitimized working in industry. We regularly compete with good university offers in our hiring. As with academic departments, some people already here got excited by what was being done by the new people and adopted the methods as well.

That is, the firm experienced rapidly expanding revenues based on discoveries made using the traditional technologies, and applied large parts of those new resources to acquire the intellectual human capital to replace the very technology which accounted for current success. We cannot say from one case study how frequently such forward-looking decision-making occurs, but clearly it is possible that a commitment to continuous technological change is a major source of persistent success in high-technology industries. Even in the current period with a relatively stable research budget, the firm is using turnover to hire in targeted areas which go substantially 
beyond the initial bioscience breakthroughs discussed above.

\section{NBS/NBF Differences in Applications of Biotechnology}

There is an ongoing controversy in the pharmaceutical industry as to whether incumbent firms have really adopted biotechnology or only a part of it. As we have seen above, our respondents say that when one compares how rDNA has been integrated in basic research drug discovery, their firm "is now indistinguishable from Genentech and other major biotech companies in how research is done." Biotech company executives sometimes assert that the major pharmaceuticals now use cloned targets to search for the same kind of "small molecule" drugs they have always produced rather than really using biotechnology to produce "large molecule" therapies. In part this sort of self-conceptualization must be seen as an attempt to define for the financial markets a view in which the speaker's firm has a competitive advantage. If the new biotech firms do not dominate on science, few of them could hope to remain competitive with the incumbent firms which have outstanding track records in clinical testing, regulatory affairs, and marketing. One popular scenario for the pharmaceutical industry sees the major firms concentrating on the three latter activities and increasingly buying their drug discoveries from the NBFs, thus converting a fixed to a variable cost.

However, this scenario does not recognize the considerable value of integrating testing, regulatory, and marketing considerations with decisions on areas of concentration for research and which drug candidates to continue working on. Perhaps more importantly, the R\&D out-sourcing scenario does not recognize that it is all but impossible for a firm to be an intelligent buyer of research unless the firm has an ongoing capability of doing leading-edge research. Thus,

[our] basic strategy is excellent in-house research. This lets us make better decisions with respect to establishing relationships with NBFs and, if the right 
occasion were to arise, purchase of an NBF. We have internal evaluators who can adequately assess their research quality. We feel that we have turned down some stupid deals made by others!

Nor does the view that this major incumbent firm is indistinguishable in its research technology from the major NBFs adequately allow for the very real strengths that this sort of firm may have which are not available, without substantial additional investment, to the NBFs. Such additional assets could well induce the incumbent firm to use technologies available to it either in addition to or as a substitute for those available to the NBFs.

We found some evidence in our interviews that there were indeed technologies possessed by the incumbent firm which were viewed by its scientists as providing competitive advantage.

[We have] a competitive advantage in a great history of chemistry. This could have been a disadvantage if there was great resistance to change. It is easy to make snide comments that less thought is required [using combinatorial chemistry] than traditional methods. So leadership has been required to support those who adopt the new technology and to reward those who accelerate the process of drug discovery. [The firm] also has an amazing collection of chemicals that other companies do not have.

Certainly the envelope theorem suggests that having more technologies available has the potential to reduce costs. The issue is whether the firm optimizes over the full range of opportunities, and at least this respondent acknowledges the dangers at the root of the immutability hypothesis and indicates that he believes that they have been overcome. In complementary field work on drug manufacturing (rather than discovery), Gary P. Pisano (1994) found that large pharmaceutical firms could shorten the process development time by laboratory experimentation for chemicalbased drugs but not for biotechnology-based drugs. This suggests that the manufacturing 
strengths of these firms are not easily transferred to other technologies.

Research executives at this large incumbent firm state that in fact they try both ends, constructing or identifying targets for drugs and production of drugs by biological processes. They believe that recently "there have not been a lot of successful new proteins; so it looks like the 'low fruit' was picked pretty early. The remaining areas of application, like septic shock, have proved to be very complex." Indeed, they would argue that "The biotechs have themselves become less optimistic about proteins as therapeutics and thus have moved away from proteins and set up combinatorial chemistry groups of their own."

At this point we see no metric to measure the differences in research strategy between any NBF/NBS pair much less a typical one. We do believe that the case illustrates that the differences may be smaller than popularly believed and that there is no necessary presumption that any differences favor the new entrants over the incumbents.

\section{NBS/NBF Differences in Providing Information to Financial Markets}

Discussions with firm executives suggested that the significantly higher number of products in development reported by NBFs relative to NBSs, other things equal, may reflect different financial reporting approaches conditioned by different financial circumstances:

... biotech firms seem to announce drugs in development earlier. [We hate] to raise hopes that are very often disappointed and so release relatively little information until the principle is proven in humans near the end of Phase 2 clinicals. Publications by scientists early on are fine, but as a company we try not to raise expectations since we neither want to raise patients' hopes without being able to deliver nor to violate our fiduciary responsibilities to not make unfounded claims. It also is something of a competitive advantage not to blab early about 
what seems to be promising....

And in another context:

We don't do a lot of public relations aimed at the current price of our stock. We believe that if we deliver the fruits of excellent research the stock price will take care of itself. The strategic orientation is rather different when you aren't pressed to raise money to cover the burn rate... ${ }^{17}$ On the other hand, because of the importance of breakthroughs in the area of AIDS, we broke our usual policy and have been disclosing information about our AIDS drug development earlier than normal...

This sort of reported difference in announcement policies suggest that caution is warranted with respect to interpreting products-in-development differences as due to greater NBF research productivity.

\section{Human Resource Policies during the Transformation}

Our previous research summarized in Section I above indicates that star scientists combining genius and knowledge of emergent technologies are the gold deposits around which firms and their success were built subsequent to the biotech breakthroughs. These scientists had the ability to become a founder of a NBF, earning in some cases literally hundreds if not thousands of millions of dollars when the firm was taken public. In addition, star scientists may be pursuing personal goals of scientific achievement, including perhaps the Nobel prize. Japanese respondents point to factors making it impossible there to either start one's own firm or to pursue scientific achievement outside the university as factors holding back their country's commercialization of biotechnology (Zucker and Darby 1994). The ability of university-based scientists to start their own firms in the 1980 s and continue affiliation with their university and 
active scientific publication provided opportunities which could not be offered by any major pharmaceutical company. However, the ability of a biotech star to break the bank declined dramatically in the latter half of the 1980s as the techniques diffused more widely.

By 1985 when this incumbent firm launched its effort to transform its technological identity, it could offer an overall employment package which was attractive to a number of the very best scientists.

\section{Publication Policy}

Unlike the reported case for Japan, this firm -- and they believe much the same is true at other major pharmaceutical firms -- follows a very liberal policy on scientific publication. Beyond a possible brief delay to prepare patent filings, the firm encourages publication of research results. ${ }^{18}$ The policy is rationalized as follows:

We see some danger of losing our competitive advantage by publishing, but a much greater danger if we do anything that deters the best scientists from coming here. Further, we need for our scientists to have great reputations in order to bring others like them to [the firm]. We are the beneficiaries of world-wide scientific research, and thus we also need to contribute to this pool of scientific knowledge, creating a public good.... Relative to NBFs, [we] may believe more strongly in the commonality of research tools because we have lots of other things to sell.

Zucker, Darby, and Armstrong (1994) show that star scientists affiliated with firms -- particularly those with patented discoveries -- are typically much more highly cited by other scientists than stars working in universities $;{ }^{19}$ so the ability to pursue and publish scientifically interesting and important research would not appear to disadvantage this firm relative to NBFs where arguably 
the scientist-entrepreneur must devote more of his or her time to management activities.

One of the firms we studied in Japan, as well as some other large pharmaceutical firms, have attempted with some success to attract top scientists by establishing a quasi-independent, almost academic bioscience research institute which has some interaction with the separate applied R\&D group. Separate basic and applied groups had existed for a time at the subject firm, but were integrated prior to and independently of the decision to adopt biotechnological methods company-wide. Our respondents viewed the independent institute model as a less productive approach and reported no conflict between the integrated research group approach and recruitment of top scientists.

\section{Incentives}

A large pharmaceutical firm like the one studied here can offer a very attractive compensation and working-conditions package for outstanding scientists. Research teams, organized around a specific target and led by a champion, operate internally as "mini-companies;"

so the leader can enjoy much of the research independence experienced by the scientistentrepreneur in a firm without the same risk, initial sacrifice, and pressures.

The manager with operational responsibility for research is certainly supportive of individual initiative:

An important part of my job is to avoid bureaucracy at all costs so as to keep the science productive. The research teams in effect are many "small companies." My job is to nurture these small units, identify leaders, try to add in the areas that will be important, and to convince people to stop projects that aren't going anywhere without squelching creativity.

Further the firm has the ability to very quickly shift substantial resources to support promising 
ideas.

While the firm certainly does not offer the upside potential one enjoys in one's own firm, neither is there the downside, and there are very substantial financial incentives for top scientists. The corporate compensation philosophy is to reward for success. "There is a single basic measure of research productivity: Are you finding therapeutic compound candidates?" For those who are successful, incentive compensation in the form of bonuses and stock options can form a very substantial portion of the total package.

A key incentive plan for research scientists was instituted in 1985 in addition to the corporate-wide plans. Under this drug-discoverer system, several scientists, who played a major role in identifying a new drug candidate, are granted stock options that vest at specific mileposts in the development of the new drug candidate. The option price of the stock is the market price at time of issue. Recently, the program has been expanded to include other team members who have made important contributions to the discovery and development of the compound. These options would also vest in line with the milepost schedule.

Economists cannot help noting that under such a stock option systems, managers profit from lower current stock prices so long as favorable news eventually emerges and is reflected in the stock price at the time they exercise their options. Thus, except for employees about to leave the firm, the incentive system is consistent with the policy of not discussing products in development (except in scientific journals) until they have been successfully proven in humans. 


\section{The Role of Collaborations}

\section{Collaborations involving University Faculty and Students}

Collaborations with university professors, their students, and their departments are common, often quite informal, and rarely publicly acknowledged:

Nearly every research program [here] has at least 1 university collaboration. Our scientists are told that its their job to find out what is important in their field worldwide and bring it into [the firm]. That is, scientists [here] should think about themselves as running the research for the whole world, and then bring in those other people who are needed to do that research.

Copublishing is about as good an indicator as you can get of commonality of interests between [the company] and an academic collaborator. Although formal relationships are on a publicly available list, many relationships are not publicly acknowledged. We focus on a group of major universities which we support and whose students we actively recruit, so recruitment of students would not generally indicate collaboration with their professor. We don't hire collaborators just because they were collaborators.

In this and other fieldwork we have repeatedly validated the usefulness of linking academic scientists to firms by bibliometric research on patterns of co-publication. As indicated in Section I above, this concept of linkage is powerfully predictive of firm success when academic star scientists are involved.

The company provides support for students, junior faculty, and relevant departments as well as entering into direct collaborations with particular professors. The collaborations may 
involve little more than informal exchanges of reagents needed in each other's research to more elaborate and long-lasting efforts with particular therapeutic goals. The firm's expertise in knocking out particular genes through rDNA and in using drugs that knock out their effects, tools which get at gene expression, makes the firm a particularly attractive collaborator for university scientists.

\section{Collaborations with Other Firms}

While involved in multiple marketing arrangements with large and small firms and basicresearch collaborations with small firms, the firm generally does not collaborate on basic research with other large firms. This lack of collaboration with large firms is not a matter of policy, but rather reflects the difficulties involved in working out complicated issues on marketing rights and other things that are not so difficult with the small biotechs where who can and will do what is more obvious.

With respect to research collaborations with small NBFs, the firm is especially interested in collaborations where the particular expertise held by others is needed for a particular project but is not thought worthwhile to build up internally. Sometimes successful collaborations reverses that judgement and leads the firm to undertake acquisition of the capability internally. Collaborations are not seen as shortcuts to acquiring new technologies for internal use. As discussed above, since the firm's strategy emphasizes excellent in-house research, collaborations with other firms do not play a central part in their effort to identify new drugs. 


\section{Did the Incumbents Generally Lag in the Biotech Revolution?}

We have seen that out incumbent firm started a bit late in the biotech revolution, but then devoted enough resources to transform its research technology to state of the art. There is a natural question as to whether this is a peculiarity of the particular firm which we studied or whether this pattern might have been followed more generally by major pharmaceutical companies. A definitive analysis of these issues is beyond the scope of the present paper, but it is possible to shed some light on the generalizability as well as provide some useful information by considering patterns of affiliation and linkage of stars with NBEs and also patterns of patenting of genetic sequences by firms.

\section{Patterns of Affiliation and Linkage of Star Scientists}

As discussed in Section I above, Zucker, Darby, and Armstrong (1994) validated a method of measuring the strength of connection between star scientists and commercial enterprises by counting the number of publications written by a star giving the particular firm as an affiliation -- or, if the star lists another affiliation -- written by a star with a coauthor who gives the firm as his or her affiliation (in which case the star is said to be linked to the firm). There is some evidence that scientists who are nearby are likely to be more involved with the firm than those farther away, so we classify linked stars by whether they are in the same BEA-defined functional economic area as the firm, in another U.S. area, or are affiliated with a foreign organization. Firms with access to leading edge science as evidenced by such affiliations and linkages perform significantly better than the vast majority of enterprises which lack such access.

Table 4 reports the history of such affiliations and linkages of stars to particular NBEs classified as dedicated biotech firms (NBFs), major pharmaceutical firms (some NBSs), and other 
incumbent subunits (the remaining NBSs) for the periods 1976-1980, 1981-1985, 1986-1990. As we see, during the first five years of the biotech revolution only one well-known NBF had the intellectual human capital which we are measuring here. In the second five years, 17 firms had demonstrated substantial access to intellectual human capital of which almost 24 percent were major pharmaceutical firms and the remainder were NBFs. Quantitatively, the pharmaceuticals lagged further, however, with all 97 articles by affiliated stars being published by stars affiliated with NBFs and only 19 percent of 52 linked articles linked to pharmaceutical firms. In the third five-year period 1986-1990 there appears to be evidence of a general catch-up effort by pharmaceutical firms. Pharmaceutical firms (including the subject of our case study) begin to have star scientists publishing as their employees (11 percent) and their share of linked articles rises to 24 percent (excluding the nascent group of incumbent firms in other industries with significant scientific capital).

\section{Patterns of Patent Production}

Figure 1 indicates that while the science diffused rapidly in the late 1970s in terms of initial publications of stars, patenting of genetic sequences did not boom until the mid 1980s. Figure 2 provides the data indicating a similar pattern when the quantities are limited to U.S. values only. GenBank has data on 3353 patents granted through the end of 1990, of which we were able to link 611 or 18.2 percent of the world total to 21 of the 34 firms examined in Table 4. ${ }^{20}$ Table 5 provides annual data for total numbers of genetic-sequence patents granted to the major pharmaceuticals with ties to stars, to the corresponding NBFs, and their sum. For convenience, the sums are provided for 1980-1985, 1986-1990, and 1980-1990. Again, we find that the major pharmaceuticals lagged behind the dedicated biotech firms but then began catching up quickly in the late 1980 s: they had only 8.7 percent of total patents for $1980-1985$, but this 
rose to 21.3 percent in 1986-1990. Given an average lag of perhaps two years between application and granting of the patent, this performance is even more remarkable.

\section{Tentative Conclusions on Generalizability}

In the early years of the biotech revolution a few great scientists who were also great entrepreneurs recognized the value in the pharmaceutical industry of the scientific breakthroughs being made. Few if any outsiders could adequately judge whether their vision was right and probably none would or could pay a conventional compensation package which would match their true worth when the tacit knowledge essential to biotechnology was held in very few hands and brains. Some of these scientists proved right in their vision and became multimillionaires or billionaires. Others, though perhaps equally able and visionary, proved unlucky in their choice of problems or approaches and did not do as well, though we have found few star scientists who became principals of firms before 1986 and are not by now multimillionaires. Certainly some very good scientists who do not have the record of achievement of our stars also were lucky and are very rich men and women today, but their odds were considerably diminished from those of equally situated stars.

After 1985 the science diffused rapidly and such extraordinary returns do not appear to have been there for the star scientists, and empirically Zucker, Darby, and Brewer (1994) report that the stars no longer played such a key role in determining the location of new entrants using biotechnology. It is certainly reasonable that the combination of technological successes and the more affordable compensation demands of top biotech scientists made this period an attractive one for the firm in our case study and the other firms highlighted in Tables 4 and 5 to begin a wrenching and still expensive transformation of their technological identities.

Clearly not all major pharmaceutical firms have transformed their technological identity. 
However, the firm we studied has, and we find quantitative evidence that a number of such firms have followed a similar path in terms of both timing and success. Cookson (1995) reports that "[t]oday, genetic engineering is used daily as a laboratory tool by every research-based pharmaceutical and biotech company" and quotes Dr. Francois L'Eplattanier, head of R\&D for Ciba of Switzerland: "Genetic engineering is absolutely essential for us. If we were not active in genetic engineering, we would be out of the game entirely by the beginning of the next century." Of course recognition of the competitive necessity to transform the firm's technological identity is not the same thing as achieving that transformation in an effective way so that the firm's superior performance is maintained. In future research, we shall test possible determinants of the ability to transform suggested by the case study, such as the technical level of top management. 


\section{Conclusions}

We can draw a number of significant conclusions from the case study reported here:

(a) We have evidence that in one major incumbent firm, the biotechnology revolution fundamentally changed the firm's technology identity, a counter-example to the hypothesis that these identities are immutable and consistent with the hypothesis that persistently successful firms maximize their wealth by transforming their technological identity as required to remain competitive in the face of technological revolutions. (b) Senior management with the scientific ability to assess the breakthroughs championed the technological transformation. (c) The technological transformation was achieved primarily through hiring new personnel embodying the new technology and incorporating them into the existing structure. Special subunits played only a transitional role, and collaborations and joint ventures with university scientists and NBFs were used primarily to augment internal expertise with explicit decision-making on the issue of whether this expertise was worth developing internally. (d) There is some evidence that biotechnology applications in the incumbent firm are more likely to be used in combination with other technologies than in NBFs which tend to use biotechnology for both discovery and production of new therapeutic entities. This difference in emphasis may result in value-enhancing synergies for the incumbent firm because of the wealth of related knowledge which makes for more effective, possibly different, applications of the new technologies. (e) University-firm collaborations are ubiquitous, often non-public, and best identified in quantitative analyses by copublishing. Hiring is not significantly related to such collaborations. (f) The firm is capable of recruiting star scientists with an overall working-conditions/employment package which includes, for those with identifiable contributions to drug discovery, stock options which vest as the drug candidate progresses through clinical trials and FDA approval. (g) While not all incumbent 
major pharmaceutical companies have changed their technological identities, we were able to identify another seven or eight such firms which seem to be following a similar path both in terms of involving top scientific talent and in terms of patenting success. 


\section{REFERENCES}

Baum, Joel A. C., "Organizational Ecology," in Stewart Clegg, Walter Nord, and Cynthia Harley, eds., Handbook of Organizational Theory. London, England: Blackwell, 1995 in press.

Brezis, Elise, Paul Krugman, and Daniel Tsiddon, "Leapfrogging: A Theory of Cycles in National Technological Leadership, " National Bureau of Economic Research Working Paper No. 3886, October 1991.

Cohen, Stanley, A. Chang, Herbert Boyer, and R. Helling, "Construction of Biologically Functional Bacterial Plasmids in vitro, "Proceedings of the National Academy of Sciences, 1973, 70: 3240-3244.

Comanor, William S., "The Political Economy of the Pharmaceutical Industry," Journal of Economic Literature, September 1986, 24: 1178-1217.

Cookson, Clive, "Essential Engineering: How Different Is Biotechnology?", Financial Times, April 25, 1995, p. 10.

DiMasi, Joseph, "Trends in Drug Development Costs, Times, and Risks," Drug Information Journal, 1995, 29: 375-384.

DiMasi, Joseph, Henry Grabowski, and John Vernon, "R\&D Costs, Innovative Output, and Firm Size in the Pharmaceutical Industry, "working paper, Tufts Center for the Study of Drug Development, December 1994.

DiMasi, Joseph, Ronald W. Hansen, Henry Grabowski, and Louis Lasagna, "Research and Development Costs for New Drugs by Therapeutic Category: A Study of the U.S. Pharmaceutical Industry," PharmacoEconomics, February 1995, 7(2): 152-169.

Friedman, Milton, Price Theory, Chicago, IL: Aldine Publishing Co., 1976.

GenBank, Release 81.0, machine readable data base, Bethesda, MD: National Center for Biotechnology Information, February 15, 1994.

Grabowski, Henry, and John Vernon, "A New Look at the Returns and Risks to Pharmaceutical R\&D," Management Science, July 1990, 36(7): 804-821.

Grabowski, Henry, and John Vernon, "Returns to R\&D on New Drug Introductions in the 1980s," Journal of Health Economics, November 1994, 13: 383-406.

Hannan, Michael T., and John Freeman, "Structural Inertia and Organizational Change," American Sociological Review, April 1984, 49(2): 149-164. 
Hedberg, Bo, "How Organizations Learn and Unlearn," in Paul C. Nystrom and William H. Starbuck, eds., Handbook of Organizational Design, Oxford: Oxford University Press, 1981

Henderson, Rebecca, "Underinvestment and Incompetence as Responses to Radical Innovation: Evidence from the Photolithographic Alignment Industry," RAND Journal of Economics, Summer 1993, 24 (2): 248-270.

Henderson, Rebecca, and Kim B. Clark, "Architectural Innovation: The Reconfiguration of Existing Product Technologies and the Failure of Established Firms," Administrative Science Quarterly, March 1990, 35(1): 9-30.

Lee, Kenneth B., Jr., and G. Steven Burrill, Biotech 95: Reform, Restructure, Renewal, The Ernst \& Young Ninth Annual Report on the Biotechnology Industry, Palo Alto, CA: Ernst \& Young. 1994.

Nelson, Richard R., and Sidney G. Winter, An Evolutionary Theory of Economic Change, Cambridge, MA: Harvard University Press, 1982.

Pisano, Gary P. , "Knowledge, Integration, and the Locus of Learning: An Empirical Analysis of Process Development, " Strategic Management Journal, 1994, 15: 85-100.

Reinganum, Jennifer F., "Uncertain Innovation and the Persistence of Monopoly," American Economic Review, September 1983, 73(4): 741-748.

Reinganum, Jennifer F., "The Timing of Innovation: Research, Development, and Diffusion," in Richard Schmalensee and Robert D. Willig, eds., Handbook of Industrial Organization, vol.1, New York, NY: North-Holland, 1989.

Sindelar, Robert D., "Overview/Preview of Current and Future Recombinant DNA-Produced Pharmaceuticals, " Drug Topics, April 20, 1992, Supplement, pp. 3-16.

Sindelar, Robert D., "The Pharmacy of the Future, "Drug Topics, May 21, 1993, 137(9): 66-84.

Singh, Jitendra V., and Charles J. Lumsden, "Theory and Research in Organizational Ecology," Annual Review of Sociology, 1990, 16: 161-195.

Tushman, Michael L., and Philip Anderson, "Technological Discontinuities and Organizational Environments, "Administrative Science Quarterly, 1986, 31: 439-465.

U.S. Congress, Office of Technology Assessment, Pharmaceutical R\&D: Costs, Risks and Rewards, OTA-H-522, Washington: U.S. Government Printing Office, February 1993.

Wooldridge, Jeffrey M., "On the Application of Robust, Regression-Based Diagnostics to Models of Conditional Means and Conditional Variances, "Journal of Econometrics, January 1991, 47: $5-46$. 
Zucker, Lynne G., and Michael R. Darby, "The Organization of Biotechnology Science and Its Commercialization in Japan, "UCLA Institute for Social Science Research Working Papers in the Social Sciences, Volume 6, Number 1, August 1994.

Zucker, Lynne G., Michael R. Darby, and Jeff Armstrong, "Intellectual Capital and the Firm: The Technology of Geographically Localized Knowledge Spillovers, " National Bureau of Economic Research Working Paper No. 4946, December 1994.

Zucker, Lynne G., Michael R. Darby, and Marilynn B. Brewer, "Intellectual Capital and the Birth of U.S. Biotechnology Enterprises," National Bureau of Economic Research Working Paper No. 4653, February 1994. [as revised August 1995] 


\section{FOOTNOTES}

1. Milton Friedman (1976, pp. 123-126) is a particularly nice presentation of this approach.

2. Jitendra V.Singh and Charles J. Lumsden (1990) and Joel A. C. Baum (1995) provide excellent recent reviews of the large population-ecology literature.

3. For some purposes, it might be preferable to exclude diagnostics from the definition of the pharmaceutical industry. However, many new firms aiming to enter the therapeutics and vaccines industry first produce diagnostics as a faster source of revenues utilizing their technologies. An extensive economics of this industry was reviewed by William S. Comanor (1986).

4. Cohen, Chang, Boyer, and Helling (1973).

5. Sindelar (1992, pp. 3-4) notes in reference to pharmaceuticals that modern biotechnological techniques can be divided "into three broad areas...." Recombinant DNA (rDNA) techniques "take identified gene sequences from one organism and place them functionally into another to permit the production of protein medicines such as human insulin, alpha interferon, and colonystimulating factors. Second, methodologies have been developed for producing monoclonal antibodies, ultrasensitive immune system-derived cells designed to recognize specific substances known as antigens that are uniquely associated with chemicals found in foreign organisms and/or humans. Developments in this field have led to their use as diagnostic agents for laboratory and home use in pregnancy tests and ovulation prediction kits and in the design of site-directed drugs such as OKT-3 for kidney transplant rejection. Finally, the development of technologies to study DND-DNA and DNA-RNA interactions has led to the formation of DNA probes (antisense technology) for a variety of research purposes with potential uses as diagnostics and therapeutics."

6. The cost estimates for the average New Chemical Entity (NCE) approved vary substantially with the quoted OTA estimate near the upper end. Analysts using an after-tax concept of cost and/or a lower cost of capital than the OTA's (14 percent declining linearly to 10 percent over the process of development to marketing approval), obtain estimates in the one or two hundreds of millions of dollars. (See, e.g., Joseph DiMasi 1995, DiMasi, Henry Grabowski, and John Vernon 1994, DiMasi, Ronald W. Hansen, Grabowski, and Louis Lasagna 1995, Grabowski and Vernon 1990, 1994, and U.S. Congress, Office of Technology Assessment 1993.)

7. In commenting on an earlier draft, respondents from the case-study firm (see Section II below) observed, "we agree that having 'stars' at the firm is essential, but it is not sufficient for a fully effective organization. Also needed is creativity in the management of people and processes."

8. For details, see Zucker, Darby, and Marilynn B. Brewer (1994).

9. These stars are only 0.8 percent of all the authors reported in GenBank up to 1990 but are authors of 17.3 percent of all the articles.

10. The variables in Table 1 are defined as follows (see source for details) where the subscript $i$ means in BEA area $i$ and the subscript $t$ means in year $t$ :

ACSTAR $_{\text {it }} \quad$ number of active stars

$\mathrm{ACCOLL}_{\mathrm{it}} \quad$ number of active collaborators 
ACSTARSQ $_{\text {it }}$

ACCOLLSQ $_{\text {it }}$

8689STAR

$8689 \mathrm{COLL}_{\text {it }}$

8689STARSQ it $_{\text {it }}$

8689COLLSQ

QUAL1 $_{\mathrm{i}}$

FEDGRANT $_{i}$

VENTCAP $_{\text {it }}$

$\mathrm{EMP}_{\text {it }}$

$\mathrm{EJOB}_{\text {it }}$

E/PRATIO, square of number of active stars

square of number of active collaborators

number of active stars if $\mathrm{t}=1986,1987,1988$, or $1989 ; 0$ otherwise

number of active collaborators if $t=1986,1987,1988$, or 1989; 0 otherwise square of number of active stars if $t=1986,1987,1988$, or 1989 ; 0 otherwise

square of number of active collaborators if $t=1986,1987,1988$, or 1989 ; 0 otherwise number of top-quality bioscience universities in 1983-84 NAS survey number of bioscientists supported by federal grants in 1979-80 number of venture capital firms total employment (all industries) average earnings per job (all industries)

S\&P 500 earnings-price ratio

11. The variables in Tables 2 and 3 are defined as follows (see source for details) with each observation corresponding to one of the NBEs in the California sample:

DNBF Categorical variable: 1 if the NBE is a NBF; 0 otherwise

FIRMAGE Age of NBE in 1989; 1990 - date of founding

RTECH Categorical variable: 1 if the NBE uses the rDNA technology; 0 otherwise

WSAFFIL Article-weighted affiliated stars: sum over all stars of the number of articles written by each star while affiliated with the NBE at any time 1976-1989

WSLINKLO Article-weighted linked local stars: sum over all stars of the number of articles written by each star during 1976-1989 which (a) lists the star at a university located in the NBE's BEA, and (b) is coauthored with one or more other scientists who is (are) listed as affiliated with the NBE

WSUNABEA Article-weighted unaffiliated local stars: sum over all stars of the number of articles written by each star during 1976-1989 which (a) does not list the star as affiliated with any NBE and (b) does list the star as affiliated with a university located in the NBE's BEA

WSUNTILO Article-weighted untied local stars: WSUNABEA - WSLINKLO

12. We note that American universities clearly dominate the global market for post-secondary education. This occurs, we believe, precisely because of their success in institutionalizing and rewarding continual self-transformation.

13. The firm actually was one of the first to market a biotech product, but this product was developed in large part by university scientists who themselves founded NBFs. Nonetheless, this alliance is evidence of management awareness of the commercial importance of biotechnology very early in the 1980 s.

14. In fieldwork in Japan, we noted that senior research personnel at two major pharmaceutical firms were envious of the ability of American top-management to understand and support the necessary technological transformation. In a third such firm, the only Japanese firm to have any star scientists as employees through 1990, senior research personnel attributed the firm's early adoption of biotechnology to the vision and adamant insistence of the CEO that these breakthroughs would transform their industry if not indeed lead to replacement of the traditional 
industry.

15. See footnote 13 above.

16. A firm scientists explains the advantages of this change: "For example, schizophrenia is a disease involving excess dopamine, and existing drugs operate by suppressing the action of dopamine. This is effective, but results in difficulties with motor function also controlled by dopamine. We can now identify subtypes of dopamine receptors and develop drugs which operate on the relevant subtypes without interfering with the operation of other subtypes. Thus, using biotech permits us to develop effective drugs which are safer and have fewer side effects."

17. The "burn rate" is the term used by analysts specializing in NBFs for the [negative] "sum of the net cash flow from operating activities per month, plus net cash flows from investing activities per month, plus capital spending per month." (Kenneth B. Lee Jr., and G. Steven Burrill 1994, p. 54) The survival index is the "burn rate divided into existing cash, cash equivalents, short-term investments, and long-term marketable securities. This calculation reflects the number of months a company can survive at it existing net burn rate" in the absence of offbook resources or commitments, regulatory approvals which can dramatically alter operating cash flows, or sales of fixed assets or debt or equity.

18. "Sometimes there is a delay due to patenting, but when I was in academe I observed a tendency to delay and skim the cream using new discoveries before publishing them."

19. The ratio is 6.5 times as many citations comparing firm scientists with patents to university scientists without patents, where in each case the comparison is restricted to the elite group of star scientists.

20. We matched genetic-sequence patents to 8 of the 9 major pharmaceutical firms, 13 of the 22 dedicated biotech firms, but found no genetic sequence patents for the 3 other NBSs. Of course, the latter group were late on the scene and may appear in patent data after the 1990 cutoff in the data which we have so far analyzed. The case-study firm was in the middle of its group in terms of frequency and onset of patenting. 
Table 1

Poisson Regressions of Annual Births of New Biotech Firms, Subunits, and Enterprises, 1976-89

\begin{tabular}{|c|c|c|c|}
\hline Dep. Var. & $\mathrm{BNBF}_{\text {it }}$ & BNBS $_{i t}$ & $\mathrm{BNBE}_{\mathrm{it}}$ \\
\hline Constant & $\begin{array}{l}-4.843^{* * *} \\
(.4094)\end{array}$ & $\begin{array}{l}-5.673^{* * *} \\
(.9024)\end{array}$ & $\begin{array}{l}-4.177^{* *} \\
(.3145)\end{array}$ \\
\hline $\operatorname{ACSTAR}_{\mathrm{it}}$ & $\begin{array}{l}0.414^{* * *} \\
(.0952)\end{array}$ & $\begin{array}{c}0.323 \\
(.1652)\end{array}$ & $\begin{array}{l}0.384^{* * *} \\
(.0729)\end{array}$ \\
\hline $\operatorname{ACCOLL}_{\mathrm{it}}$ & $\begin{array}{l}-0.006 \\
(.0528)\end{array}$ & $\begin{array}{c}.0003 \\
(.1051)\end{array}$ & $\begin{array}{l}-0.011 \\
(.0432)\end{array}$ \\
\hline $\operatorname{ACSTARSQ}_{\mathrm{it}}$ & $\begin{array}{l}-0.016^{* *} \\
(.0060)\end{array}$ & $\begin{array}{l}-0.016^{*} \\
(.0080)\end{array}$ & $\begin{array}{l}-0.016^{* * *} \\
(.0046)\end{array}$ \\
\hline $\mathrm{ACCOLLSQ}_{\mathrm{it}}$ & $\begin{array}{c}0.001 \\
(.0017)\end{array}$ & $\begin{array}{c}0.002 \\
(.0028)\end{array}$ & $\begin{array}{c}0.001 \\
(.0014)\end{array}$ \\
\hline 8689STAR $_{\mathrm{it}}$ & $\begin{array}{l}-0.227^{*} \\
(.1128)\end{array}$ & $\begin{array}{l}-0.519 * \\
(.2371)\end{array}$ & $\begin{array}{l}-0.314^{* *} \\
(.0962)\end{array}$ \\
\hline $8^{8689 C \text { OLL }_{i t}}$ & $\begin{array}{c}0.096 \\
(.0712)\end{array}$ & $\begin{array}{c}0.233 \\
(.1413)\end{array}$ & $\begin{array}{c}0.141^{*} \\
(.0595)\end{array}$ \\
\hline 8689STARSQ $_{\text {it }}$ & $\begin{array}{c}0.007 \\
(.0066)\end{array}$ & $\begin{array}{c}0.018 \\
(.0104)\end{array}$ & $\begin{array}{c}0.010 \\
(.0053)\end{array}$ \\
\hline 8689COLLSQ & $\begin{array}{l}-0.001 \\
(.0020)\end{array}$ & $\begin{array}{l}-0.004 \\
(.0033)\end{array}$ & $\begin{array}{l}-0.002 \\
(.0016)\end{array}$ \\
\hline QUAL1 $_{i}$ & $\begin{array}{l}0.440^{* * *} \\
(.1095)\end{array}$ & $\begin{array}{c}0.479 * \\
(.2050)\end{array}$ & $\begin{array}{l}0.431^{* *} \\
(.0908)\end{array}$ \\
\hline FEDGRANT $_{\mathrm{i}}$ & $\begin{array}{l}0.973^{* * *} \\
(.1117)\end{array}$ & $\begin{array}{l}1.114^{* * *} \\
(.2958)\end{array}$ & $\begin{array}{l}0.943^{* * *} \\
(.0891)\end{array}$ \\
\hline VENTCAP $_{i t}$ & $\begin{array}{l}-0.029^{* * *} \\
(.0070)\end{array}$ & $\begin{array}{l}-0.027^{*} \\
(.0117)\end{array}$ & $\begin{array}{l}-0.028^{* * *} \\
(.0054)\end{array}$ \\
\hline $\mathrm{EMP}_{\mathrm{it}}$ & $\begin{array}{l}-0.110 \\
(.0583)\end{array}$ & $\begin{array}{l}-0.052 \\
(.0984)\end{array}$ & $\begin{array}{l}-0.064 \\
(.0441)\end{array}$ \\
\hline $\mathrm{EJOB}_{\text {it }}$ & $\begin{array}{l}0.123^{* * *} \\
(.0181)\end{array}$ & $\begin{array}{l}0.113^{* *} \\
(.0395)\end{array}$ & $\begin{array}{l}0.109^{* * *} \\
(.0148)\end{array}$ \\
\hline E/PRATIO, & $\begin{array}{l}-0.022 \\
(.0314)\end{array}$ & $\begin{array}{l}-0.056 \\
(.0698)\end{array}$ & $\begin{array}{l}-0.018 \\
(.0241)\end{array}$ \\
\hline $\begin{array}{l}\text { celihood } \\
\text { tricted }\end{array}$ & $\begin{array}{r}-945.9 \\
-1628.7\end{array}$ & $\begin{array}{l}-386.8 \\
-607.9\end{array}$ & $\begin{array}{l}-1249.0 \\
-2189.8\end{array}$ \\
\hline
\end{tabular}

Note: Standard errors (adjusted by Wooldridge 1991, Procedure 2.1) are in parentheses below coefficients. $\mathrm{N}=2562$. Probability $\mathrm{t}>\mathrm{x}:{ }^{*}<.05, * *<.01,{ }^{* * *}<.001$

Source: Zucker, Darby, and Brewer (1994), Table 5. 
Table 2

Estimates for Products in Development

Poisson Regressions, Dependent Variable: PRODDVLP

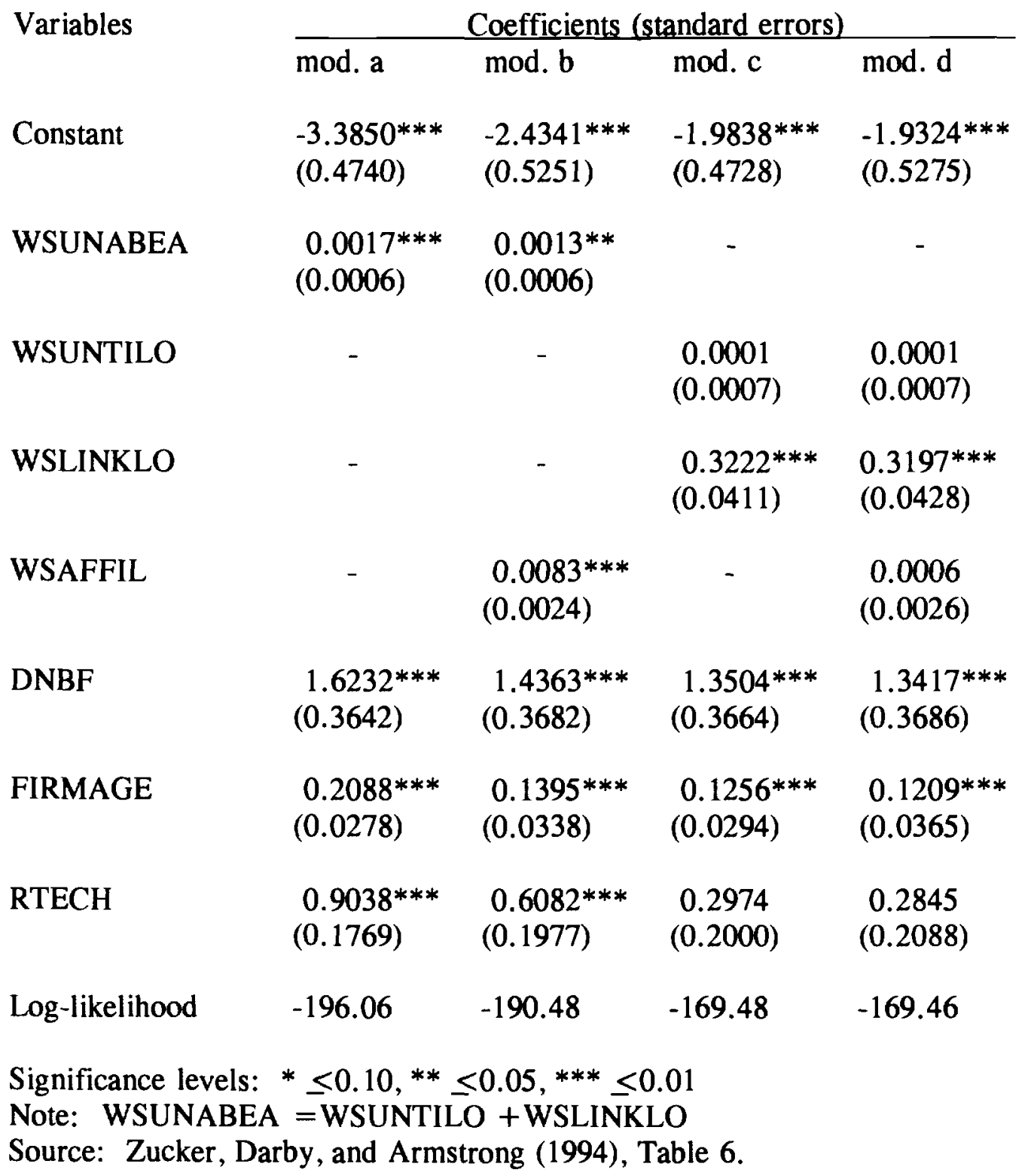


Table 3

Estimates for Products on the Market

Poisson Regressions, Dependent Variable: PRODMKT

\begin{tabular}{|c|c|c|c|c|}
\hline \multirow[t]{2}{*}{ Variables } & \multicolumn{4}{|c|}{ Coefficients (standard errors) } \\
\hline & mod. a & mod. $b$ & $\bmod . \mathrm{c}$ & mod. $d$ \\
\hline Constant & $\begin{array}{l}1.3210^{* * *} \\
(0.2135)\end{array}$ & $\begin{array}{l}1.4630^{* * *} \\
(0.2206)\end{array}$ & $\begin{array}{l}1.4615^{* * *} \\
(0.2178)\end{array}$ & $\begin{array}{l}1.4953^{* * *} \\
(0.2228)\end{array}$ \\
\hline WSUNABEA & $\begin{array}{l}-0.0004 \\
(0.0004)\end{array}$ & $\begin{array}{l}-0.0005 \\
(0.0004)\end{array}$ & - & - \\
\hline WSUNTILO & - & - & $\begin{array}{l}-0.0006 \\
(0.0004)\end{array}$ & $\begin{array}{l}-0.0006 \\
(0.0004)\end{array}$ \\
\hline WSLINKLO & - & - & $\begin{array}{l}0.1378 * * * \\
(0.0504)\end{array}$ & $\begin{array}{c}0.1143 * \\
(0.0640)\end{array}$ \\
\hline WSAFFIL & - & $\begin{array}{l}0.0062^{* *} \\
(0.0028)\end{array}$ & - & $\begin{array}{c}0.0024 \\
(0.0035)\end{array}$ \\
\hline DNBF & $\begin{array}{l}-0.3456 * * * \\
(0.1330)\end{array}$ & $\begin{array}{l}-0.3714 * * * \\
(0.1338)\end{array}$ & $\begin{array}{l}-0.3398^{* *} \\
(0.1330)\end{array}$ & $\begin{array}{l}-0.3512 * * * \\
(0.1342)\end{array}$ \\
\hline FIRMAGE & $\begin{array}{l}0.0803^{* * *} \\
(0.0206)\end{array}$ & $\begin{array}{l}0.0678^{* * * *} \\
(0.0215)\end{array}$ & $\begin{array}{l}0.0673^{* * *} \\
(0.0213)\end{array}$ & $\begin{array}{l}0.0643^{* * *} \\
(0.0218)\end{array}$ \\
\hline RTECH & $\begin{array}{l}-0.4990^{* * *} \\
(0.1211)\end{array}$ & $\begin{array}{l}-0.5595^{* * *} \\
(0.1256)\end{array}$ & $\begin{array}{l}-0.5778^{* * *} \\
(0.1263)\end{array}$ & $\begin{array}{l}-0.5880^{* * * *} \\
(0.1275)\end{array}$ \\
\hline Log-likelihood & -299.64 & -297.57 & -296.42 & -296.20 \\
\hline
\end{tabular}


Table 4

Publications by Stars Affiliated with or Linked to NBEs

Variables

No.

of

NBEs

\begin{tabular}{lccc}
\multicolumn{4}{c}{ Publication Counts of Stars } \\
\hline Affiliated & Linked & Linked in & Linked \\
Stars & in BEA & other US & foreign
\end{tabular}

1976-1980:

Dedicated Biotech Firms 1

Major Pharmaceutical Firms 0

9

0

0

0

0

0

0

Other Incumbent Subunits 0

0

0

0

Total for All Firms

1

9

0

0

0

1981-1985:

Dedicated Biotech Firms 13

Major Pharmaceutical Firms 4

97

20

12

10

Other Incumbent Subunits 0

0

2

7

1

$0 \quad 0$

0

0

Total for All Firms

17

97

22

19

11

1986-1990:

Dedicated Biotech Firms 19

68

16

30

6

Major Pharmaceutical Firms 8

Other Incumbent Subunits 3

8

3

9

4

0

2

2

0

Total for All Firms

30

76

21

41

10

1976-1990:

Dedicated Biotech Firms 22

174

36

42

16

Major Pharmaceutical Firms 9

8

5

16

Other Incumbent Subunits 3

0

2

182

43

60

21 
Table 5

Patents Granted to Firms with Affiliated or Linked Stars

1980-1990

$\begin{array}{lccc}\text { Period } & \begin{array}{c}\text { Major } \\ \text { Pharmaceutical Firms }\end{array} & \begin{array}{c}\text { Dedicated Biotech } \\ \text { Firms }\end{array} & \text { All Firms } \\ 1980 & 0 & 2 & \\ 1981 & 0 & 4 & 2 \\ 1982 & 4 & 17 & 21 \\ 1983 & 0 & 9 & 9 \\ 1984 & 1 & 29 & 30 \\ 1985 & 4 & 34 & 38 \\ 1986 & 3 & 49 & 52 \\ 1987 & 10 & 18 & 28 \\ 1988 & 45 & 101 & 146 \\ 1989 & 43 & 152 & 195 \\ 1990 & 7 & 79 & 86 \\ 1980-85 & 9 & 95 & 104 \\ 1986-90 & 108 & 399 & 507 \\ 1980-90 & 117 & 494 & 611\end{array}$


Figure 1

Cumulative Number of Stars and Genetic-Sequence Patents Granted in the World

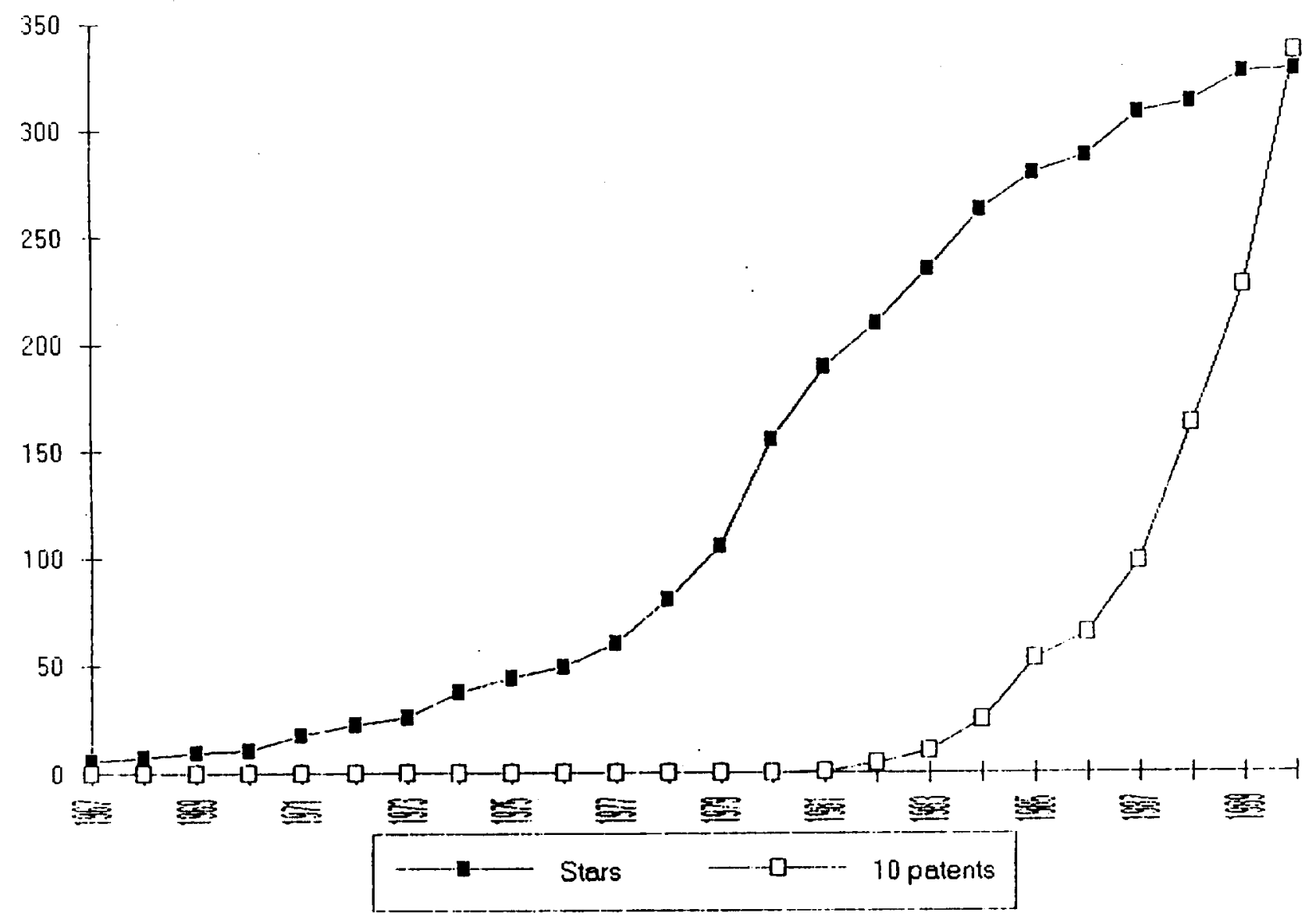

Source: GenBank ${ }^{\mathrm{TM}}$, Release 81.0 , February 15,1994 , and calculations by the authors. 
Figure 2

Cumulative Number of U.S. Stars and U.S. Genetic-Sequence Patents Granted

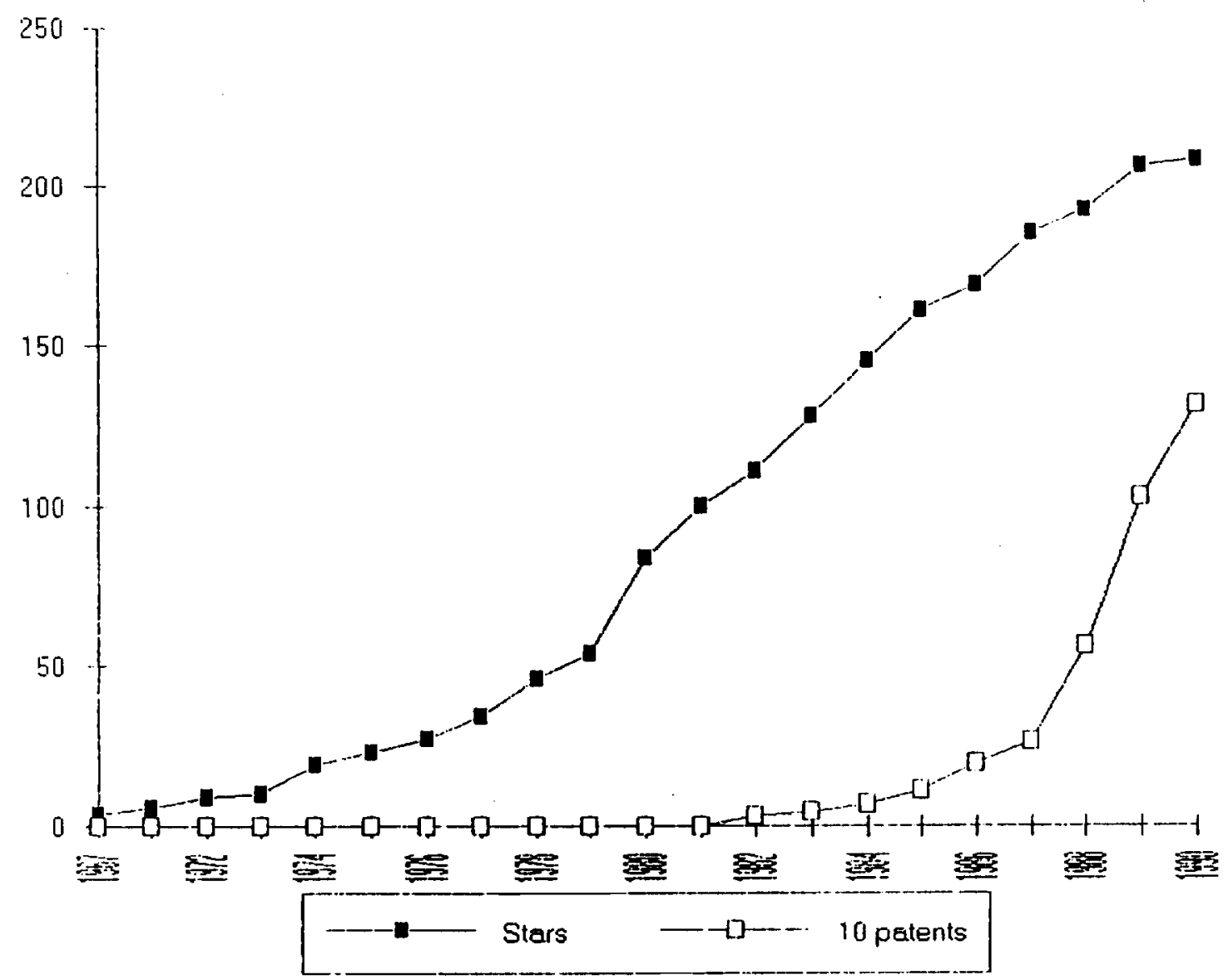

Source: GenBank ${ }^{\mathrm{TM}}$, Release 81.0, February 15, 1994, and calculations by the authors. 